\title{
Changes to soil water content and biomass yield under combined maize and maize-weed vegetation with different fertilization treatments in loam soil
}

\author{
Éva Lehoczky ${ }^{1}$, Mariann Kamuti ${ }^{1}$, Nikolett Mazsu ${ }^{1}$, Renáta Sándor ${ }^{1} 2^{*}$ \\ ${ }^{1}$ Institute for Soil Sciences and Agricultural Chemistry, Centre for Agricultural Research, Hungarian Academy of Sciences, \\ Herman Otto út. 15, 1022 Budapest, Hungary. \\ ${ }^{2}$ Grassland Ecosystem Research Unit, French National Institute for Agricultural Research, 5 chemin de Beaulieu, 63039 Clermont-Ferrand, \\ France. \\ ${ }^{*}$ Corresponding author. E-mail: sandor.renata@agrar.mta.hu
}

\begin{abstract}
Especially during early developmental stages, competition with weeds can reduce crop growth and have a serious effect on productivity. Here, the effects of interactions between soil water content (SWC), nutrient availability, and competition from weeds on early stage crop growth were investigated, to better understand this problem. Field experiments were conducted in 2013 and 2014 using long-term study plots on loam soil in Hungary. Plots of maize (Zea mays L.) and a weed-maize combination were exposed to five fertilization treatments. SWC was observed along the 0-80 $\mathrm{cm}$ depth soil profile and harvested aboveground biomass (HAB) was measured.

Significant differences were found between SWC in maize and maize-weed plots. In all treatments, measured SWC was most variable in soil depths of up to $50 \mathrm{~cm}$, and at the 8-10 leaves (BBCH19) growth stage of the crop. The greatest depletion of SWC was detected within PK treatments across the entire soil profile and under both vegetation types, with depletion also considerable under NPK and NP treatments. Biomass growth was significantly influenced by weeds in treated plots between the $\mathrm{BBCH} 13$ and 19 phenological stages, but water availability did not hamper growth rates in non-fertilized conditions. These findings suggest that, at early stages of crop growth, SWC model simulations need to include better characterisation of depth- and structure-dependent soil water uptake by vegetation.
\end{abstract}

Keywords: Soil water content; Maize weed; Phenological stage; Fertilization.

\section{INTRODUCTION}

Water resources play an important role in the development of ecosystems. Changes in water availability can have a substantial impact on ecosystems, which are a critical component of the hydrological cycle and an essential mediator between land surface and atmospheric interactions (Breuer et al., 2012). Soil is involved in many hydrological processes, including infiltration (Lichner et al., 2013), drainage to deeper layers (Wang et al., 2014), and discharge from groundwater (Wang et al., 2015).

Soil water content (SWC) is often used as an indicator of water limitation in dryland ecosystems (e.g. Matthews et al., 2008), as it controls several important chemical and biological processes (e.g. root uptake and transpiration) (Singh and Singh, 2004). However, predicting the impacts of changes in water availability can be difficult because of weed-crop interactions, with effects mediated by the competitive ability and density of the weeds and crops, edaphic and management conditions, the characteristics of species and the composition of the plant community (Valerio et al., 2013; Yeganehpoor et al., 2015). Additionally, SWC has a high spatial heterogeneity and temporal variability (Martinez et al., 2013) which affects the plantavailable transpirable pool of water (Diodato et al., 2010), according to the vegetation type and the character of the scale related pattern (Sándor, 2014; Si et al, 2015). Combinations of land use and vegetation type can also have substantial effects on SWC (e.g., to produce a unit of dry matter (DM), weeds require more water than most crop plants (Lehoczky et al., 2012; Shen et al., 2014)). Water storage is often the most limiting factor for crop yields, causing varying levels of crop stress, contingent on the developmental stage of the plant. This makes cropping systems vulnerable to drought conditions, as stored soil water is rapidly depleted during extended dry periods (e.g. Diodato and Bellocchi, 2008).

For maize (Zea mays L.), grain yield losses are caused mainly by weed competition (Lehoczky et al., 2005; Rajcan and Swanton, 2001; Yeganehpoor et al., 2015), which may be responsible for up to 34 percent of crop loss worldwide (Abouziena et al., 2015). According to Lehoczky et al. (2013), in the early growth stage of maize, weed competition can reduce biomass by up to $64 \%$ compared to weed-free maize. However nutrient supply (Berzsenyi et al., 2011; Fodor et al., 2013) and soil water availability (Várallyay, 2011) are also key factors in crop production efficiency (Mantovani et al., 2014). Strong correlation can be observed between changes in nutrient supply and the dominance of different weed species (Kamuti et al., 2015; Lehoczky et al., 2014). Furthermore, pest damage (Georgescu et al., 2014), heavy metal pollution (Rékási and Filep, 2006), planting density (Kivuva et al., 2014) and changes in climatic conditions during the vegetation period (Bassu et al., 2014) including dry and hot spells (Lichner et al., 2012) can have a negative effect on potential biomass production and grain yield.

Competition for soil water stocks can increase the risk of water stress periods, which reduce both crop and weed biomass production, even in humid temperate regions (Acciaresi and Guiamet, 2010). Competition for water may also alter the ability of plants to utilize other resources, such as light or nutrients (Berger et al., 2010). Water intake by weeds reduces the amount of available SWC for cultivated plants (Lehoczky, 2004; Patterson and Flint, 1983) while crops also decrease the soil moisture content of the fertile zone. The outcome of competition for water resources depends on the relative abilities of weed and crop vegetation to tolerate SWC deficit conditions (Patterson, 1995). 
A further important factor for harvested aboveground biomass (HAB) production and grain yield is the amount of available essential macronutrients such as nitrogen $(\mathrm{N})$, potassium (K) and phosphorus (P) in the form of $\mathrm{NH}_{3}, \mathrm{~K}_{2} \mathrm{O}$ and $\mathrm{P}_{2} \mathrm{O}_{5}$. Several studies (Song et al., 2010) found that SWC was significantly influenced by fertilization, as a result of nutrient stimulation of plant growth. $\mathrm{N}$ fertilization has been shown to increase root and biomass growth, leading to the absorption of more water by plants during the growing season in waterlimited regions (Wang et al., 2013). P and $\mathrm{K}$ can also stimulate plant growth, and can alter the impacts of $\mathrm{N}$ addition on an ecosystem (Wendel et al., 2011).

The vegetation-SWC-fertilization relationship is inherently complex and involves many factors (e.g. meteorological and environmental circumstances, and applied management options such as extensive or intensive fertilization treatments, planting density and crop rotation) (Brant et al., 2012). Maize seedlings are more sensitive to the presence of neighbouring weeds during the critical period of early competition for water and light (Hall et al., 1992). Increasing weed biomass can have a negative impact on the ability of maize to compete for water during the critical competition period (from 4-6 to 12-14 leaves stage) (Kazinczi et al., 2008). Water stress during the vegetative dry matter accumulation period can limit plant height, as well as the amount of harvested aboveground biomass (HAB), but does not necessarily decrease the quantity of grain yield (Rajcan and Swanton, 2001). The relative competitive ability of species has been shown to vary with soil-moisture level (Nichols et al., 2015; Wiese and Vandiver, 1970), while Azeez et al. (2005) found that weed cover moderated rates of evapotranspiration leading to higher SWC in weed-maize combined plots than under weed-free vegetation.

Several multidisciplinary studies have considered SWCmaize-weed interactions (Pivec and Brant, 2009; Acciaresi and Guiamet, 2010; Berger et al., 2010), taking into account the significant effects of land use practice and vegetation cover on the water cycle during the growing period. Notwithstanding these efforts, there is limited understanding of the nature of such interactions during early phenological growth stages of crops. The present study uses a multi-fertilization field experiment to address 4 fundamental questions: (1) do changes in SWC effect maize and weed growth during the early phenological stages?, (2) how do different macronutrient fertilization treatments interact with SWC along the soil profile?, (3) is there an effect of limited nutrient supply on the measured HAB?, (4) what variations are associated with the different vegetation and fertilization treatments, and how can variation be quantified in a multi-treatment study?

\section{MATERIALS AND METHODS Study site}

The study was carried out in a long-term (2003-2014) fertilization experiment in a maize monoculture (PR 4983 (2013); Mv 277 (2014)) at Nagyhörcsök (latitude 4651'54"N; longitude $18^{\circ} 36^{\prime} 28.8^{\prime \prime} \mathrm{E}$, altitude 142 metres above sea level) in Hungary, during the late spring - early summer of 2013 and 2014. Meteorological conditions were recorded during the period of investigation (Fig. 1). The region has a continental climate, with relatively cold winters and hot summers. Based on the long-term (1967-2014) daily meteorological database of the Institute for Soil Sciences and Agricultural Chemistry, the average annual temperature is about $11.7^{\circ} \mathrm{C}$, in summer $22.2^{\circ} \mathrm{C}$, and in winter $0.6^{\circ} \mathrm{C}$. The pilot area receives on average $522.5 \mathrm{~mm}$ rainfall annually. Groundwater was located at a depth of 13-15 $\mathrm{m}$ and the area was prone to drought (Kádár and Csathó, 2015).

The studied area has chernozem loam soil with lime deposits (FAO-Calcaric Phaeosem; USDA-Calcic Hapludoll) (Table 1).

\section{Experiment study design}

Five $4.9 \mathrm{~m} \times 15 \mathrm{~m}\left(73.5 \mathrm{~m}^{2}\right)$ randomly blocked plots were designed with different levels of N, P and $\mathrm{K}$ supplied in three replications (Table 2). Fertilizers containing $\mathrm{P}$ and $\mathrm{K}$ were spread before autumn ploughing whilst $\mathrm{N}$ fertilizer was applied before sowing. Two $2 \mathrm{~m} \times 2 \mathrm{~m}\left(4 \mathrm{~m}^{2}\right)$ herbicide-free blocks were separated in each fertilization treatment plot, about $2.5 \mathrm{~m}$ from the centre point for weed surveying in 6 repetitions. Herbicide-free plots were covered whilst herbicide (Turbo Jumbo; a.i. bentazone, dicamba, methyl-oleate, methyl-palmera, nicosulfuron) was applied to weed-free treatments post emergence.

Volumetric water content was recorded using an IMKO TRIME-FM3 device, which is a time domain reflectometry (TDR) based system with a broad range of applications. One special fiberglass tube was installed in the middle of each fertilization-treatment plot for recording SWC under weed-free maize (M) monoculture in 3 replicates. Further plexi tubes were

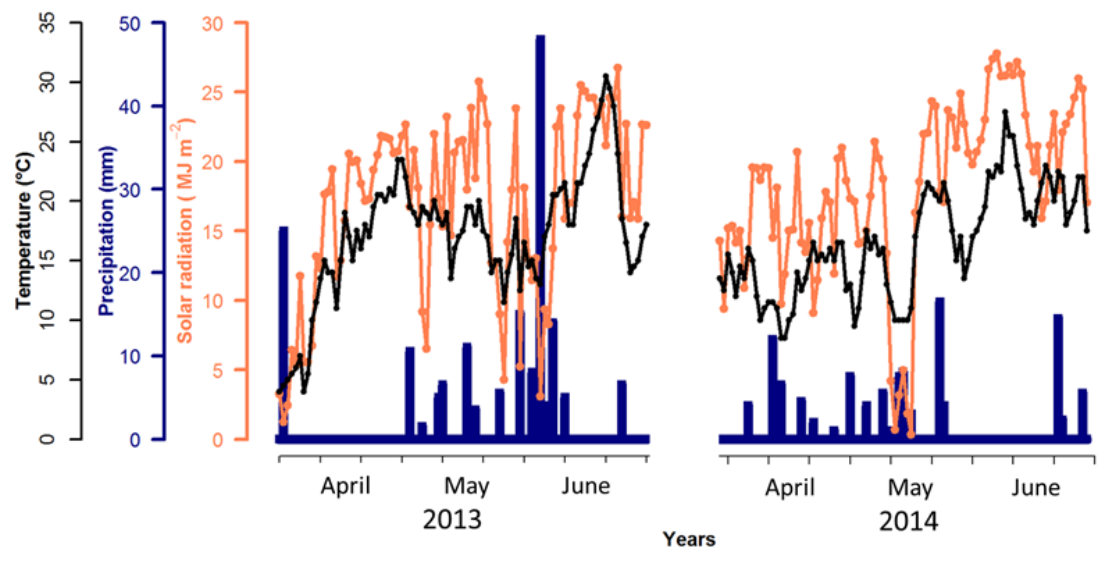

Fig. 1. Average daily temperature $\left({ }^{\circ} \mathrm{C}\right)$ (black line), precipitation $(\mathrm{mm})$ (blue bars) and solar radiation $\left(\mathrm{MJm}^{-2}\right)$ (orange line) conditions at Nagyhörcsök (Hungary) during the data survey spells (between April and June in 2013 and 2014.) Solar radiation values were estimated by RadEst Software (Fodor, 2012). 
Table 1. Average chemical and physical soil properties of the $0-30 \mathrm{~cm}$ soil layer at Nagyhörcsök (Hungary) experimental site in 2003 and 2013.

\begin{tabular}{|c|c|c|c|c|c|c|c|}
\hline \multicolumn{8}{|c|}{ Chemical properties } \\
\hline $\begin{array}{c}\text { Measuring } \\
\text { year }\end{array}$ & Treatments & OM (\%) & $\begin{array}{c}\mathrm{Al}-\mathrm{P}_{2} \mathrm{O}_{5} \\
\left(\mathrm{mg} \mathrm{kg}^{-1}\right)\end{array}$ & $\begin{array}{c}\mathrm{Al}-\mathrm{K}_{2} \mathrm{O} \\
\left(\mathrm{mg} \mathrm{kg}^{-1}\right)\end{array}$ & Salt $(\%)$ & $\mathrm{pH}_{\mathrm{KCl}}$ & $\begin{array}{c}\mathrm{CaCO}_{3} \\
(\%)\end{array}$ \\
\hline 2003 & $\begin{array}{l}\text { Multi-plot } \\
\text { average }\end{array}$ & 2.95 & 90 & 167 & 0.02 & 7.1 & 3.9 \\
\hline \multirow{5}{*}{2013} & Control & 3.05 & 76 & 126 & 0.03 & 7.25 & 4.82 \\
\hline & PK & 3.21 & 187 & 256 & 0.04 & 7.28 & 4.21 \\
\hline & NK & 3.20 & 79 & 215 & 0.04 & 7.28 & 4.69 \\
\hline & NP & 3.23 & 169 & 154 & 0.05 & 7.22 & 3.24 \\
\hline & NPK & 3.16 & 193 & 209 & 0.05 & 7.22 & 3.12 \\
\hline \multicolumn{8}{|c|}{ Physical properties (multi-plot average) } \\
\hline & $\begin{array}{c}\mathrm{BD} \\
\left(\mathrm{g} \mathrm{cm}^{-3}\right)\end{array}$ & Sand $(\%)$ & Silt (\%) & Clay $(\%)$ & $\begin{array}{c}K_{S} \\
\left(\mathrm{~cm} \mathrm{~d}^{-1}\right)\end{array}$ & $\begin{array}{c}\mathrm{FC} \\
\left(\mathrm{m}^{3} \mathrm{~m}^{-3}\right)\end{array}$ & $\begin{array}{c}\mathrm{WP} \\
\left(\mathrm{m}^{3} \mathrm{~m}^{-3}\right)\end{array}$ \\
\hline 2003 & 1.45 & 18.9 & 56.0 & 25.1 & 94.6 & 0.33 & 0.16 \\
\hline
\end{tabular}

$\mathrm{BD}$ - bulk density; $K_{S}$ - saturated hydraulic conductivity (Fodor et al., 2011); FC - field capacity; WP - wilting point

Table 2. Applied annual macronutrient-fertilization doses on maize monoculture at Nagyhörcsök (Hungary) between 2003 and 2014.

\begin{tabular}{cccc}
\hline \multirow{2}{*}{ Treatment } & \multicolumn{3}{c}{ Dose } \\
\cline { 2 - 4 } & $\begin{array}{c}\mathrm{N} \\
\left(\mathrm{kg} \mathrm{ha}^{-1} \mathrm{yr}^{-1}\right)\end{array}$ & $\begin{array}{c}\mathrm{P}_{2} \mathrm{O}_{5} \\
\left(\mathrm{~kg} \mathrm{ha}^{-1} \mathrm{yr}^{-1}\right)\end{array}$ & $\begin{array}{c}\mathrm{K}_{2} \mathrm{O} \\
\left(\mathrm{kg} \mathrm{ha}^{-1} \mathrm{yr}^{-1}\right)\end{array}$ \\
\hline Control & 0 & 0 & 0 \\
PK & 0 & 100 & 100 \\
NK & 150 & 0 & 100 \\
NP & 150 & 100 & 0 \\
NPK & 150 & 100 & 100 \\
\hline
\end{tabular}

settled under the $4 \mathrm{~m}^{2}$ herbicide free, weed-maize (W-M) combined cells in 3 replicates in 2013, and this number was doubled in the following year. This design enabled the influence of weed and maize cultures on SWC to be recorded in each treatment. The number of investigated SWC measuring profiles was increased under $\mathrm{W}-\mathrm{M}$ vegetation in order to mitigate variation caused by the spatial pattern of weed density under pedon scale sampling (Sándor et al., 2015). The volumetric water content of the $0-80 \mathrm{~cm}$ soil profile was recorded with $10 \mathrm{~cm}$ resolution, between sowing and the second HAB measuring date in every second week in 2013, then twice a week in 2014.

Sowing took place on April $23^{\text {rd }}$ and April $30^{\text {th }}$ in 2013 and 2014 , respectively. The harvested aboveground biomass of maize and total weed flora was determined twice during the early growing stage of maize; at 2-4 leaves (BBCH 13) and $8-10$ leaves (BBCH 19) on $4^{\text {th }}$ and $20^{\text {th }}$ of June in 2013, and on the $3^{\text {rd }}$ and $19^{\text {th }}$ of June in 2014. The study site had the following characteristic weed species: Ambrosia artemisiifolia L., Chenopodium album L., Chenopodium hybridum L., Datura stramonium L. and Sorghum halepense (L.) Pers. The two-year average weed density was approximately 130 plants per square meter on the Control, PK and NPK treatments, and $\sim 80$ plants $\mathrm{m}^{-2}$ on NK and NP fertilization plots. The maize planting density was established with 7 plants $\mathrm{m}^{-2}$. Weedy maize (wM) and weed (w) biomass was harvested from the $4 \mathrm{~m}^{2}$ herbicide-free plots whilst weed-free maize (M) was harvested from the herbicide treated section of the plots. The harvested aboveground $\mathrm{M}$, wM and w biomass values (each from a $1 \mathrm{~m}^{2}$ area) were measured after 48 hours drying at $40^{\circ} \mathrm{C}$, in order to obtain constant dry weights.

\section{Statistical analysis methods}

R Studio (RStudio Team, 2015) was used for statistical computing and visualization of in situ measured SWC and maize and weed biomass datasets from the Nagyhörcsök experimental site in 2013 and 2014. Datasets were normally distributed, independent and homogenous (according to Bartlett-test) allowing the use of ANOVA for statistical analyses.

SWC interactions with different fertilization treatments (Table 2) under each pairwise combination of vegetation types (e.g. $\mathrm{M}$ and $\mathrm{W}-\mathrm{M}$ ) were tested for using two-way ANOVA. Under W-M, the effect of the two plant groups (weed and maize) on SWC changes was inseparable, so two-way ANOVA was conducted using only $\mathrm{M}$ and $\mathrm{W}-\mathrm{M}$ vegetation types and 5 different fertilization treatments as factors on SWC.

In order to investigate $\mathrm{HAB}$ productivity under various nutrient levels three types of vegetation were distinguished: $M$, $\mathrm{wM}$ and $\mathrm{W}$. This categorisation was also used to analyse early stage competition between maize and weed. One-way ANOVA was used to test for differences in growth between the 2-4 leaves $(\mathrm{BBCH} 13)$ and 8-10 leaves $(\mathrm{BBCH} 19)$ maize phenological stages. To avoid confounding effects from differences in meteorological conditions between 2013 and 2014 (due to a severe dry spell in April of 2013, Fig. 1), two-year HAB and SWC values were selected and averaged by phenological stages for data analyses .

\section{RESULTS}

\section{Vegetation-SWC-fertilization relationship under BBCH13 phenological stage}

Changes in SWC were observed under different fertilization treatments, with the greatest difference found between Control and PK plots (Figs. 2-3); no significant differences were observed between the control and other fertilization treatments. Mean SWC values indicated increased soil moisture uptake by W-M under NPK fertilization and by both vegetation types under PK fertilization (Figs. 2-3).

Two year averaged soil moisture content was not significantly different between or within treatments and vegetation types at $0-10 \mathrm{~cm}$ or $20-40 \mathrm{~cm}$ soil depths (Table 3). The SWC of the $10-20 \mathrm{~cm}$ layer was significantly different between Control and PK treatments, and within fertilization treatments (Fig. $4 \mathrm{a}-\mathrm{c}$ ). 


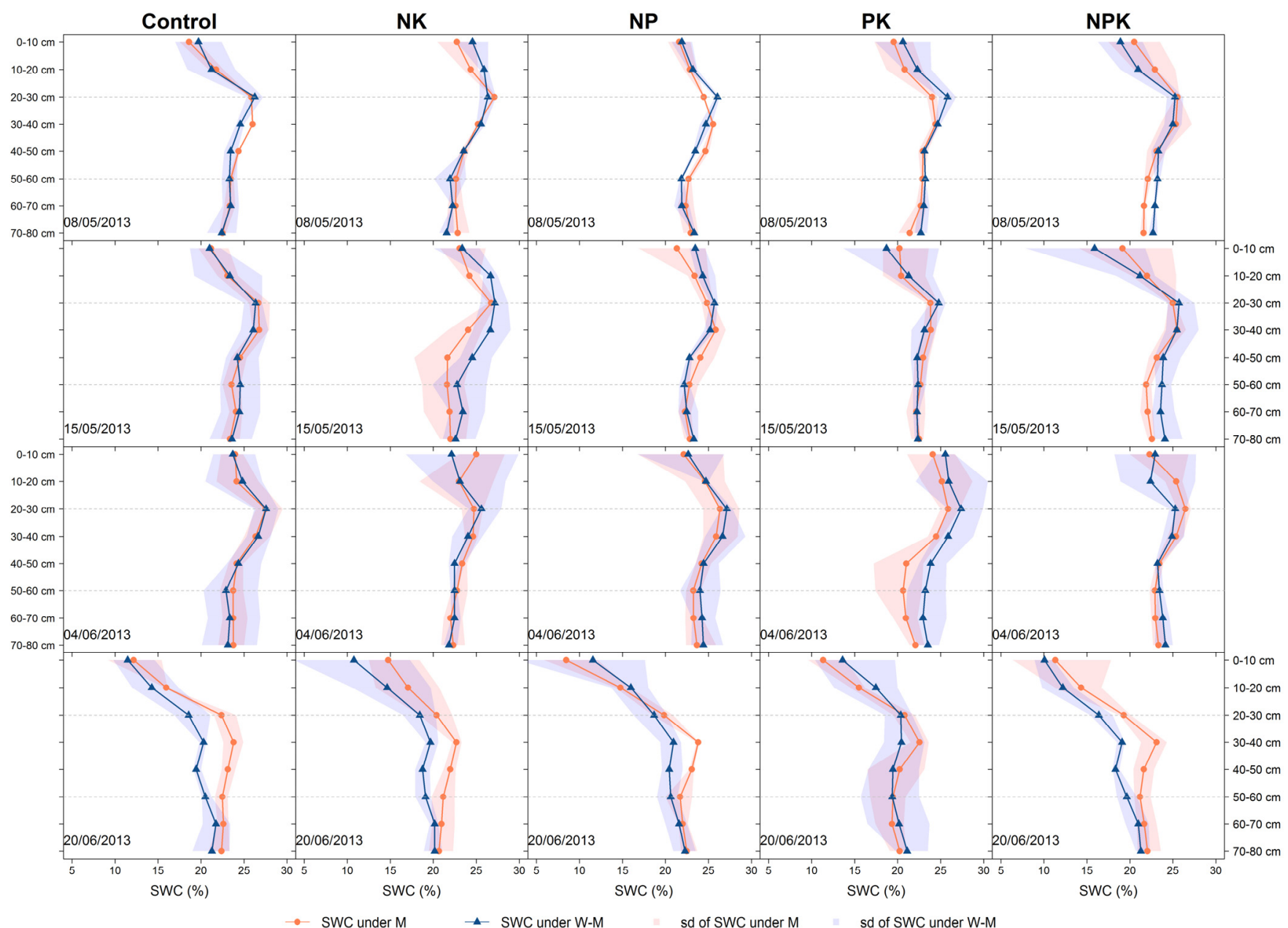

Fig. 2. Volumetric soil water content (\%) changes under maize (M, red) and weed-maize (W-M, blue) vegetation along the soil profile $(0-80 \mathrm{~cm})$ with their standard deviation (pink and blue shaded areas, respectively) in the different fertilization treatments (applied macronutrient doses as in Table 2) at Nagyhörcsök (Hungary) on the given days in 2013.

\section{Vegetation-SWC-fertilization relationship under BBCH19 phenological stage}

Overall, there was a significant difference in the SWC of the 20-30 cm soil depth layer between NPK and Control treatments under weed-maize (Probability $(\mathrm{P}(>|\mathrm{t}|))$ : 0.002$)$, but no differences were observed at shallower or deeper levels, or in other treatments (Figs. 2-3).

ANOVA revealed a number of significant differences in SWC along the soil profile between vegetation and fertilization treatments (Table 3 ). Both macronutrient treatments and vegetation had a significant effect on the SWC of the top soil layer $(0-10 \mathrm{~cm})$. For instance, there were significant differences between Control and NP, and between Control and NPK treatments. Variability of SWC was greater in the $10-20 \mathrm{~cm}$ soil layer than at other levels (residual str. err: $1.89, \mathrm{R}^{2}: 0.51, \mathrm{~F}$-stat p-value: <.000) across all treatments (Fig. 4, Table 3). Fig. 4d shows the SWC variability of the 10-20 cm depth layer across all fertilization treatments and vegetation types. The greatest difference was between Control and PK treatments $(\mathrm{P}(>|\mathrm{t}|)$ : 0.004), but further differences were computed between Control and NP (P $(>|t|): 0.1)$, and between Control and NPK (P $(>|t|)$ : $0.06)$ (Fig. 4). Variation in SWC between $20-40 \mathrm{~cm}$ depth was significant between vegetation types (namely maize and weedmaize; $\mathrm{P}(>|\mathrm{t}|)$ : 0.07), but not between fertilization treatments (Table 3). Considering the SWC, some additional significant differences were found along the soil profile. We obtained considerable differences between fertilization treatments below $50 \mathrm{~cm}$ depth (Table 3), e.g. the dissimilarity was significant between Control and PK, and Control and NPK, $\mathrm{P}<0.001$ and $\mathrm{P}<0.01$, respectively. Linear model analysis of the $60-70 \mathrm{~cm}$ depth layer showed significant differences between Control and PK, NK $(P(>|t|):<.000)$, Control and NP $(P(>|t|): 0.02)$ fertilization treatments (Table 3$)$.

\section{Relationship between HAB growing and treatments}

Analysis indicated that total biomass production (Fig. 5) was not independent of macronutrient (Table 2) and meteorological conditions (Table 1). The highest average maize and weed HAB were measured under NPK and PK treatments (Figs. $2-3)$. Considerable differences were found between the growth of maize (M), weedy-maize (wM) and weed (W) HAB under the different macronutrient treatments between the $\mathrm{BBCH} 13$ and 19 phenological stages (Fig. 6). The average biomass growth of Control maize was $67.6 \mathrm{~g} \mathrm{DM} \mathrm{m}^{-2}$, while the mean maize HAB growth was higher under NK (110.6 $\mathrm{g} \mathrm{DM} \mathrm{m}^{-2}$ ), PK treatments $\left(145.9 \mathrm{~g} \mathrm{DM} \mathrm{m}^{-2}\right)$, NP $\left(136.6 \mathrm{~g} \mathrm{DM} \mathrm{m}^{-2}\right)$ and NPK treatments $\left(188.6 \mathrm{~g} \mathrm{DM} \mathrm{m}^{-2}\right)$. The difference was significant between Control maize and NPK $(\mathrm{P}(>|\mathrm{t}|)$ : 0.002), PK $(\mathrm{P}(>|\mathrm{t}|): 0.084)$ and NP (P (>|t|): 0.089) maize. Weed biomass growth was $56.3 \mathrm{~g} \mathrm{DM} \mathrm{m}^{-2}$ whilst weedy-maize growth was 


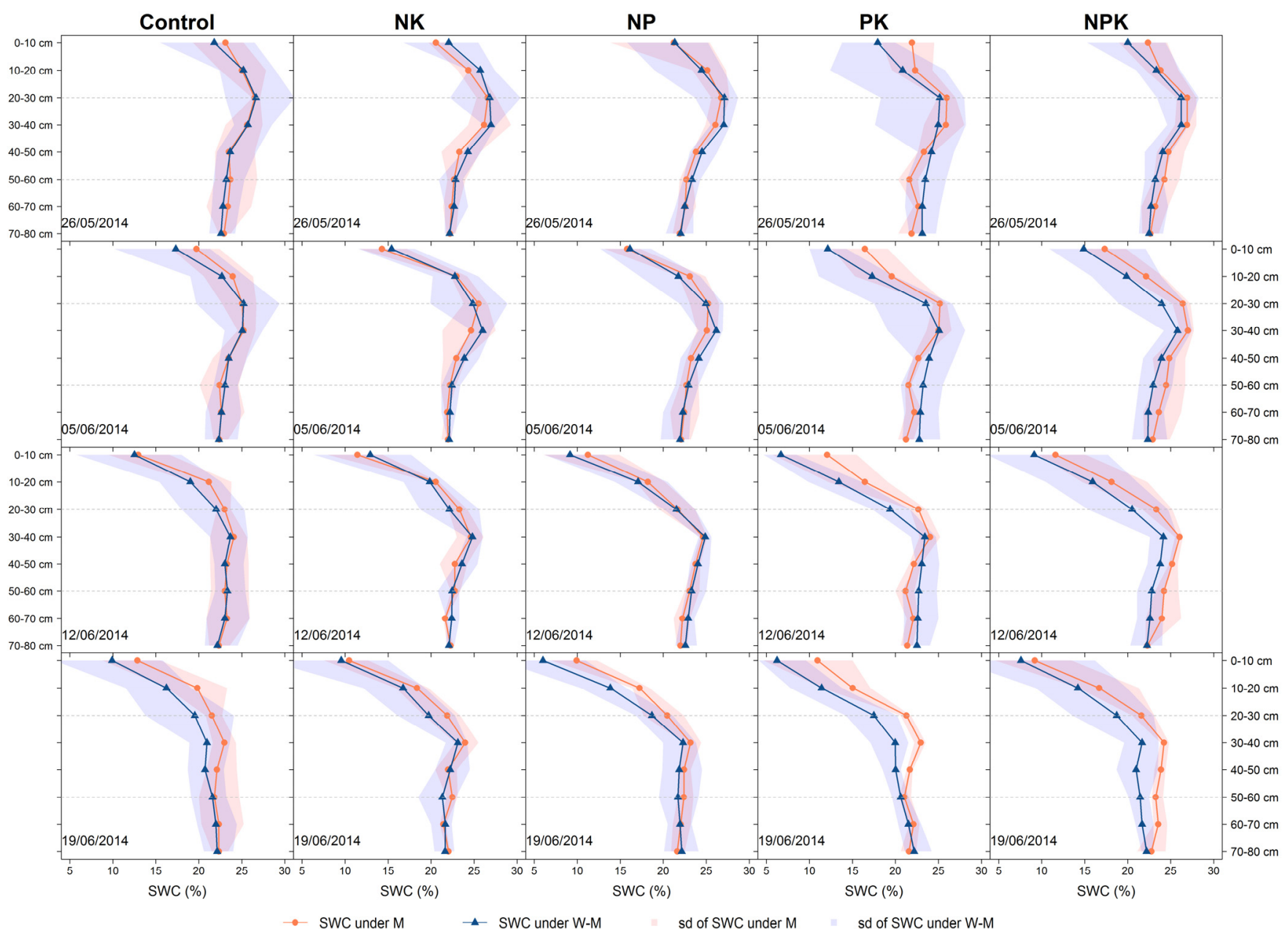

Fig. 3. Volumetric soil water content (\%) changes under maize ( $M$, red) and weed-maize (W-M, blue) vegetation along the soil profile $(0-80 \mathrm{~cm})$ with their standard deviation (pink and blue shaded areas, respectively) in the different fertilization treatments (applied macronutrient doses as in Table 2.) at Nagyhörcsök (Hungary) on the given days in 2014.

moderated (43.9 $\mathrm{g} \mathrm{DM} \mathrm{m}^{-2}$ ) in the Control site. Only NPK fertilized weed biomass growth was significantly different from the Control maize $(\operatorname{Pr}(>|t|)$ : 0.037). The median $\mathrm{HAB}$ growth of Control weedy-maize was higher than that of the weed-free maize (Fig. 6). Growth of weedy-maize biomass approached the growing rate of maize at PK treatment whilst median values were lower under other treatments.

\section{DISCUSSION}

The present study found several significant differences in SWC between vegetation and nutrient supply treatments during the early phenological stages of maize growth, and treatments also had an effect on the HAB. Measured SWC showed large variation, and this may have been caused by variation in environmental circumstances (such as rainfall events or severe drought (Fig. 1.)), or by variation in the uptake of water by vegetation (e.g. weed, maize (Figs.2-3)). There was a significant difference in the multi-treatment average of SWC between the upper (0-30 cm, A zone) and the deeper layers (30-60 cm, $\mathrm{B}$ and $60-80 \mathrm{~cm}, \mathrm{C}$ zones) along the observed soil profile under Control and PK treatments (Figs. 2-3), and considerable difference (not significant) under other fertilizations, which could have resulted from cultivation, with the $\sim 30 \mathrm{~cm}$ layer representing a typical ploughing depth. Higher spatial heterogeneity in soil texture with increasing soil depth may have been responsi- ble for the variation in observed SWC below $30 \mathrm{~cm}$, as a result of differences in soil hydraulic properties such as saturated hydraulic conductivity $\left(K_{S}\right)$.

\section{Vegetation-SWC-fertilization relationship under BBCH13 phenological stage}

In terms of the BBCH13 phenological stage, the applied fertilization treatments did not cause any radical change in SWC in any treatments (Fig. 4a). The two-year averaged $0-10 \mathrm{~cm}$ depth soil moisture content was not significantly different between and within treatments and vegetation types. Nevertheless, the spatial heterogeneity of soil properties seemed to have larger effect on the SWC than vegetation. Several significant differences were observed along the soil profile (Figs. 1-2, Table 3). For instance, SWC variability in the $50-70 \mathrm{~cm}$ zones showed higher differences in fertilization, probably owing to the spatial pattern of the soil layers. Possibly, fertilization had a greater effect on SWC below the $40 \mathrm{~cm}$ layer, because of more shallow rooting depths in the $\mathrm{BBCH} 13$ stage.

\section{Vegetation-SWC-fertilization relationship under BBCH19 phenological stage}

Significantly lower SWC was found only in the untreated compared to the PK and NPK fertilized plots at the $0-20 \mathrm{~cm}$ 

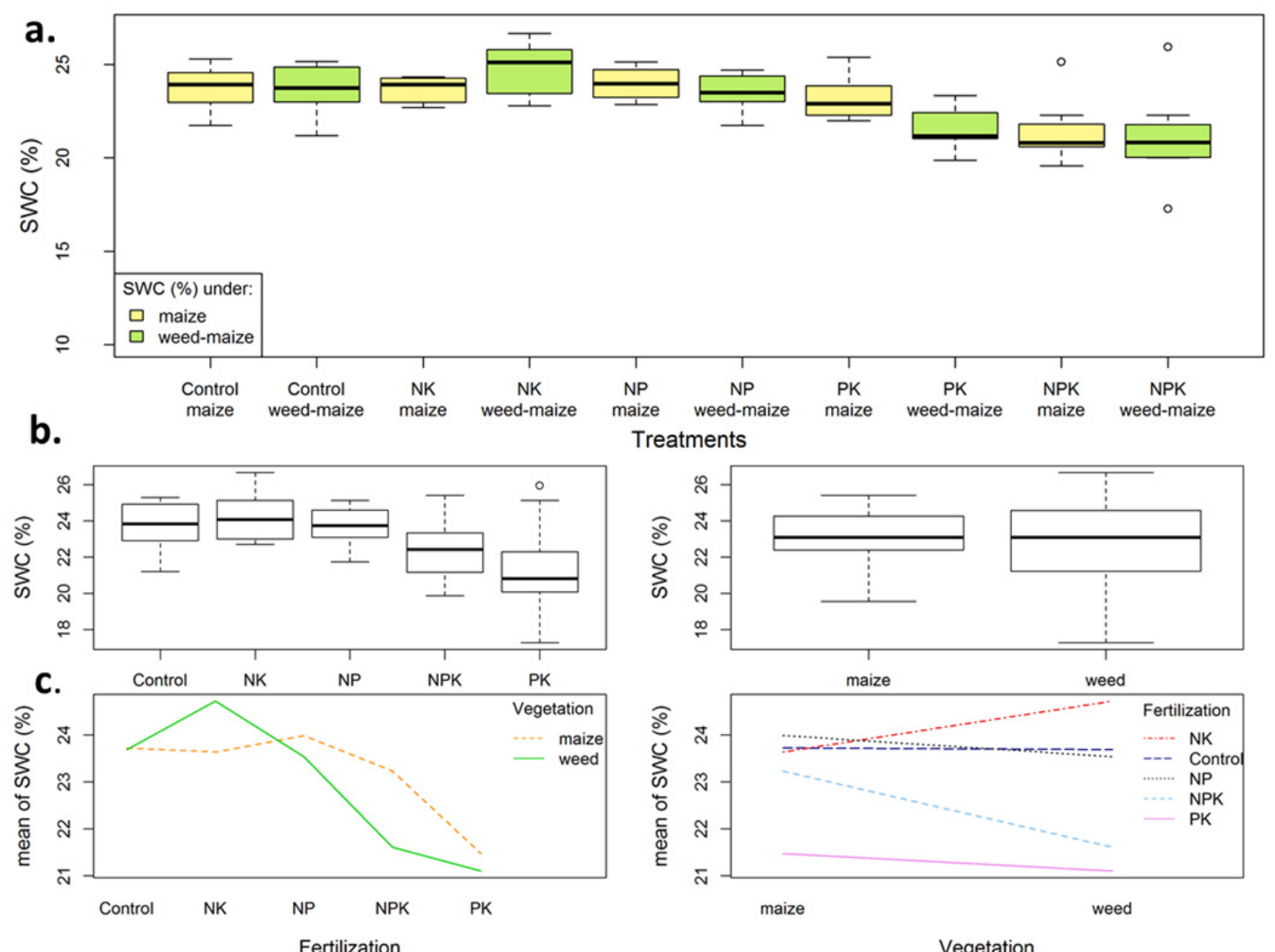

Treatments
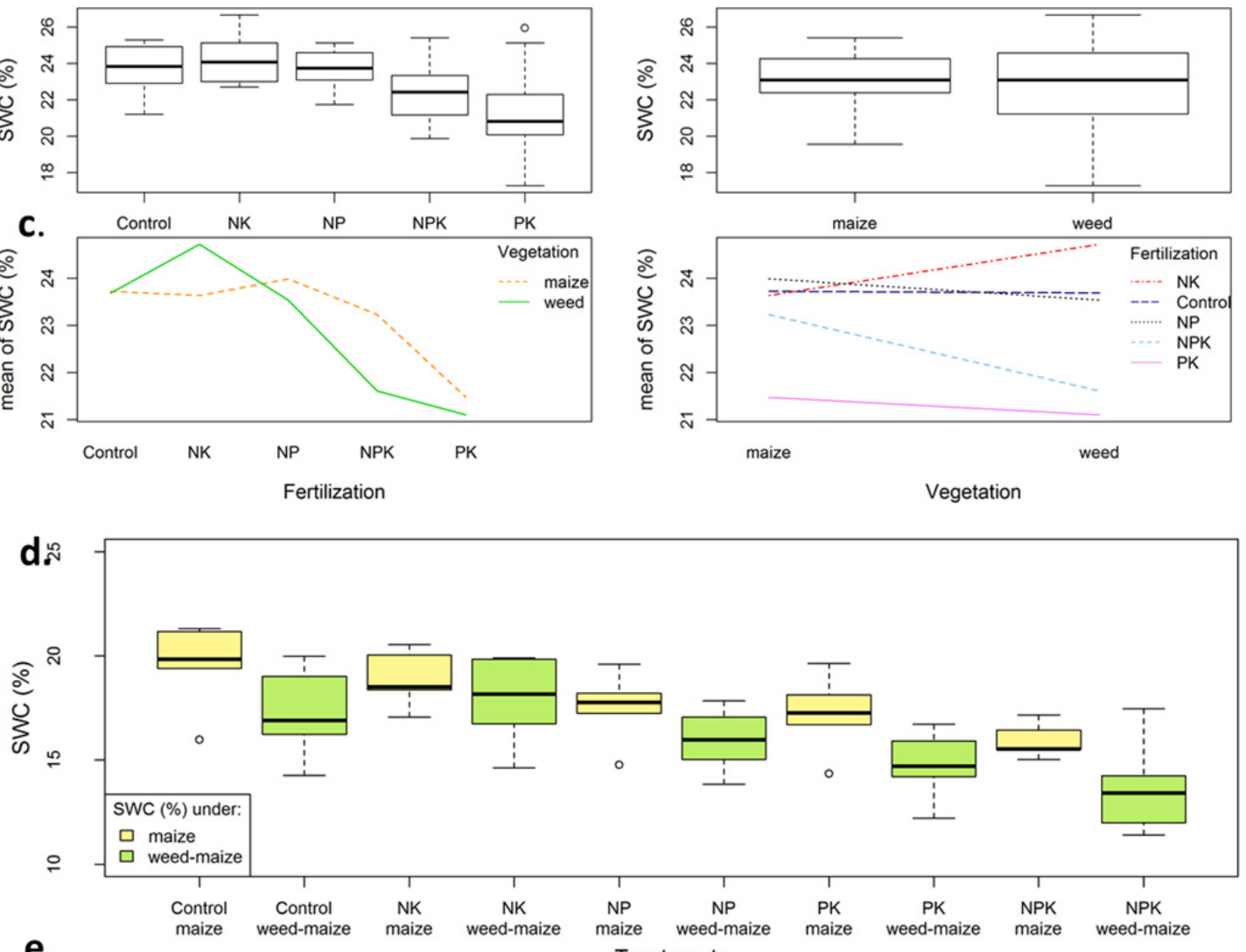

e. Treatments
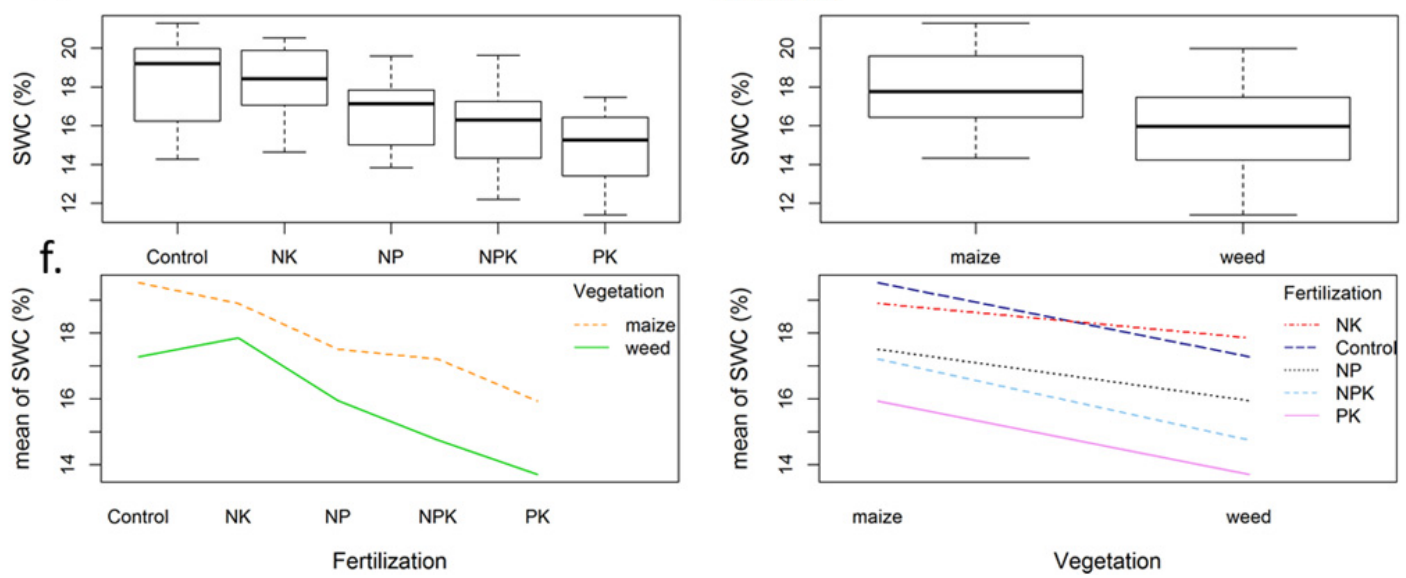

Fig. 4. Two-year volumetric SWC (\%) changes at the 10-20 cm soil depth layer for the 2-4 leaf (BBCH 13) (a, b and c) and 8-10 leaf $(\mathrm{BBCH} 19)(\mathrm{d}$, e and f) maize growth stages at Nagyhörcsök (Hungary) under maize and maize-weed vegetation and 5 fertilization treatments (Control, NK, NP, PK, NPK). (Treatment doses as in Table 2.) a., d. Boxes are delimiting the $25^{\text {th }}$ and $75^{\text {th }}$ percentiles with the median inside. Whiskers are $10^{\text {th }}$ and $90^{\text {th }}$ percentiles. SWC under maize appears with yellow shaded background whilst the maize-weed combination with green. Hollow circles indicate outliers. b., e. Distribution of SWC (\%) between fertilization and vegetation types related to all replications; c., f. and with the plot average values. 
Table 3. Results of two-way ANOVA on SWC values and N-P-K fertilization (Frt) (doses as in Table 2) and applied vegetation (V) types (maize and weed-maize) along the measured soil profile at Nagyhörcsök (Hungary) during the BBCH13 (A) and BBCH19 (B) phenological state periods. $\mathrm{R}$ indicates residuals. Asterisks indicate significance: ***: $0.001,{ }^{* *}: 0.01,{ }^{*}: 0.05,{ }^{\prime} \cdot: 0.1$.

\begin{tabular}{|c|c|c|c|c|c|c|c|c|c|c|}
\hline \multirow{2}{*}{ Depth } & \multirow{2}{*}{ Factors } & \multirow{2}{*}{ Df } & \multicolumn{2}{|c|}{ Sum Sq } & \multicolumn{2}{|c|}{ Mean Sq } & \multicolumn{2}{|c|}{ F value } & \multicolumn{2}{|c|}{$\operatorname{Pr}(>F)$} \\
\hline & & & A & $\mathrm{B}$ & A & $\mathrm{B}$ & A & $\mathrm{B}$ & A & $\mathrm{B}$ \\
\hline \multirow{4}{*}{$0-10 \mathrm{~cm}$} & Frt & 4 & 21.8 & 57.5 & 5.5 & 14.4 & 0.54 & 4.53 & 0.707 & $0.004 * *$ \\
\hline & $\mathrm{V}$ & 1 & 5.8 & 27.5 & 5.8 & 27.5 & 0.57 & 8.66 & 0.451 & $0.005 * *$ \\
\hline & Frt $\sim V$ & 4 & 20.0 & 17.9 & 5.0 & 4.5 & 0.49 & 1.41 & 0.740 & 0.247 \\
\hline & $\mathrm{R}$ & 40 & 606.8 & 127.0 & 10.1 & 3.2 & & & & \\
\hline \multirow{4}{*}{$10-20 \mathrm{~cm}$} & Frt & 4 & 80.3 & 96.6 & 20.1 & 24.2 & 9.37 & 6.78 & $<0.000 * * *$ & $<0.000 * * *$ \\
\hline & $\mathrm{V}$ & 1 & 1.4 & 45.8 & 1.4 & 45.8 & 0.64 & 12.84 & 0.428 & $<0.000 * * *$ \\
\hline & Frt $\sim V$ & 4 & 13.2 & 3.5 & 3.3 & 0.9 & 1.54 & 0.25 & 0.203 & 0.911 \\
\hline & $\mathrm{R}$ & 40 & 128.6 & 142.5 & 2.1 & 3.6 & & & & \\
\hline \multirow{4}{*}{$20-30 \mathrm{~cm}$} & Frt & 4 & 6.9 & 9.6 & 1.7 & 2.4 & 1.82 & 1.00 & 0.137 & 0.421 \\
\hline & $\mathrm{V}$ & 1 & 0.0 & 52.7 & 0.0 & 52.7 & 0.01 & 21.90 & 0.938 & $<0.000 * * *$ \\
\hline & Frt $\sim V$ & 4 & 5.2 & 6.5 & 1.3 & 1.6 & 1.37 & 0.68 & 0.254 & 0.610 \\
\hline & $\mathrm{R}$ & 40 & 57.0 & 96.2 & 0.9 & 2.4 & & & & \\
\hline \multirow{4}{*}{$30-40 \mathrm{~cm}$} & Frt & 4 & 10.0 & 10.7 & 2.5 & 2.7 & 2.04 & 1.13 & 0.101 & 0.356 \\
\hline & $\mathrm{V}$ & 1 & 0.8 & 29.6 & 0.8 & 29.6 & 0.69 & 12.49 & 0.410 & $0.001 * *$ \\
\hline & Frt $\sim V$ & 4 & 4.8 & 5.2 & 1.2 & 1.3 & 0.98 & 0.54 & 0.425 & 0.704 \\
\hline & $\mathrm{R}$ & 40 & 73.9 & 94.8 & 1.2 & 2.4 & & & & \\
\hline \multirow{4}{*}{$40-50 \mathrm{~cm}$} & Frt & 4 & 6.4 & 13.5 & 1.6 & 3.4 & 2.55 & 1.62 & $0.048 *$ & 0.188 \\
\hline & V & 1 & 2.7 & 11.7 & 2.7 & 11.7 & 4.28 & 5.65 & $0.043 *$ & $0.022 *$ \\
\hline & Frt $\sim V$ & 4 & 5.0 & 6.6 & 1.3 & 1.6 & 2.01 & 0.79 & 0.105 & 0.538 \\
\hline & $\mathrm{R}$ & 40 & 37.5 & 83.1 & 0.6 & 2.1 & & & & \\
\hline \multirow{4}{*}{$50-60 \mathrm{~cm}$} & Frt & 4 & 11.2 & 15.6 & 2.8 & 3.9 & 6.31 & 3.23 & $<0.000 * * *$ & $0.022 *$ \\
\hline & V & 1 & 1.8 & 3.1 & 1.8 & 3.1 & 3.98 & 2.58 & 0.051 . & 0.116 \\
\hline & Frt $\sim V$ & 4 & 5.2 & 5.9 & 1.3 & 1.5 & 2.92 & 1.23 & $0.028 *$ & 0.315 \\
\hline & $\mathrm{R}$ & 40 & 26.6 & 48.3 & 0.4 & 1.2 & & & & \\
\hline \multirow{4}{*}{$60-70 \mathrm{~cm}$} & Frt & 4 & 8.1 & 10.8 & 2.0 & 2.7 & 6.02 & 4.50 & $<0.000 * * *$ & $0.004 * *$ \\
\hline & $\mathrm{V}$ & 1 & 0.7 & 0.8 & 0.7 & 0.8 & 2.16 & 1.27 & 0.147 & 0.266 \\
\hline & Frt $\sim V$ & 4 & 1.7 & 4.3 & 0.4 & 1.1 & 1.27 & 1.79 & 0.290 & 0.151 \\
\hline & $\mathrm{R}$ & 40 & 20.3 & 24.1 & 0.3 & 0.6 & & & & \\
\hline \multirow{4}{*}{$70-80 \mathrm{~cm}$} & Frt & 4 & 4.6 & 4.7 & 1.1 & 1.2 & 3.62 & 4.58 & $0.010 *$ & $0.004 * *$ \\
\hline & V & 1 & 1.2 & 0.0 & 1.2 & 0.0 & 3.86 & 0.00 & 0.054 . & 0.957 \\
\hline & Frt $\sim V$ & 4 & 3.5 & 3.5 & 0.9 & 0.9 & 2.76 & 3.39 & $0.036 *$ & $0.018 *$ \\
\hline & $\mathrm{R}$ & 40 & 19.0 & 10.2 & 0.3 & 0.3 & & & & \\
\hline
\end{tabular}

soil depth. The SWC was greater at 10-20 cm depth (Fig. 4), than in the top layer, possibly as a result of evaporation and transpiration at the upper level (Table 3). SWC varied more in WM than in $\mathrm{M}$ plots (Figs. 2 and 3) probably due to the different root types and rooting depths of the weed vegetation. The variation in measured SWC (Figs. 2 and 3) was higher under weed-maize vegetation than under maize and this may have been caused by a more effective water uptake by multiple species with a greater variety of density and rooting depth. However, weed density and DM appeared to be influenced by fertilization (e.g. lower biomass production was observed under NK and NP plots, which had around half the weed density of the control plots $\left(\sim 80\right.$ plants $\cdot \mathrm{m}^{-2}$ versus $\sim 130$ plants $\cdot \mathrm{m}^{-2}$ in control plots) (Fig. 5)). The SWC of the deeper soil levels, for instance $50-70 \mathrm{~cm}$ (Table 3), showed greater differences between treatments in the BBCH19 phenological stage than in the $\mathrm{BBCH} 13$ stage, presumably due to higher water and macronutrient uptake by roots. As Figures 4d, e and f suggest, the most characteristic SWC deficit was observed under the PK, NPK and NP treatments, while the Control and NK had higher soil moisture content, probably caused by the lower weed density in the NK plot and the poor nutrient supply in the Control plot.

Presence of weed species may have had more effect on SWC between $0-50 \mathrm{~cm}$ soil depths than applied fertilization (Table 3, Figs. 2 and 3). SWC was significantly lower in weedy than in weed-less planting in the BBCH19 developmental phase. In Berger's (2010) examinations, crop water productivity was lower in weedy systems due to crop yield reductions rather than to increases in total soil water use. The results of this study are consistent with this finding even between sowing and the BBCH19 growth stage. Cerrudo et al. (2012) observed a reduction in the amount of maize DM and grain yield owing to the stress effect of neighbouring weeds in the early season. Differences in SWC observed here (Figs. 2, 3 along the observed soil profile and Fig. 4 at the $10-20 \mathrm{~cm}$ soil level) are also consistent with the findings of Abouziena et al. (2015) that many weeds are less sensitive to the available SWC than crops, as they transpire or use more water each day.

\section{Relationship between $\mathrm{HAB}$ growing and treatments}

W species growth was higher than that of wM weedy-maize in NK and NPK plots between the BBCH13 and BBCH19 phenological stages (Fig. 6). Except in the Control plot (where wM growth was greater than that of weed-free $M$ ) weedy-maize growth was slightly lower at NP and PK treatments and considerably, but not significantly reduced at other sites (Fig. 6), which may have been caused by weed species. The negative effect of the weed flora on crop biomass production might have caused the higher differences observed between weed and maize in the Control plot at a later phenological stage (Lehoczky et al., 2015). In general, there was less variation in maize growth than in the growth of weedy-maize or weeds, except in the Control treatment. The higher variation in growth in weed-maize combination plots may be related to differences between the traits of crop and weed species, for example in terms of rooting depth and transpiration (Pivec et al., 2011). Lehoczky et al. $(2006,2012)$ observed that the weeds required more water than the maize or wheat, thus water could be 


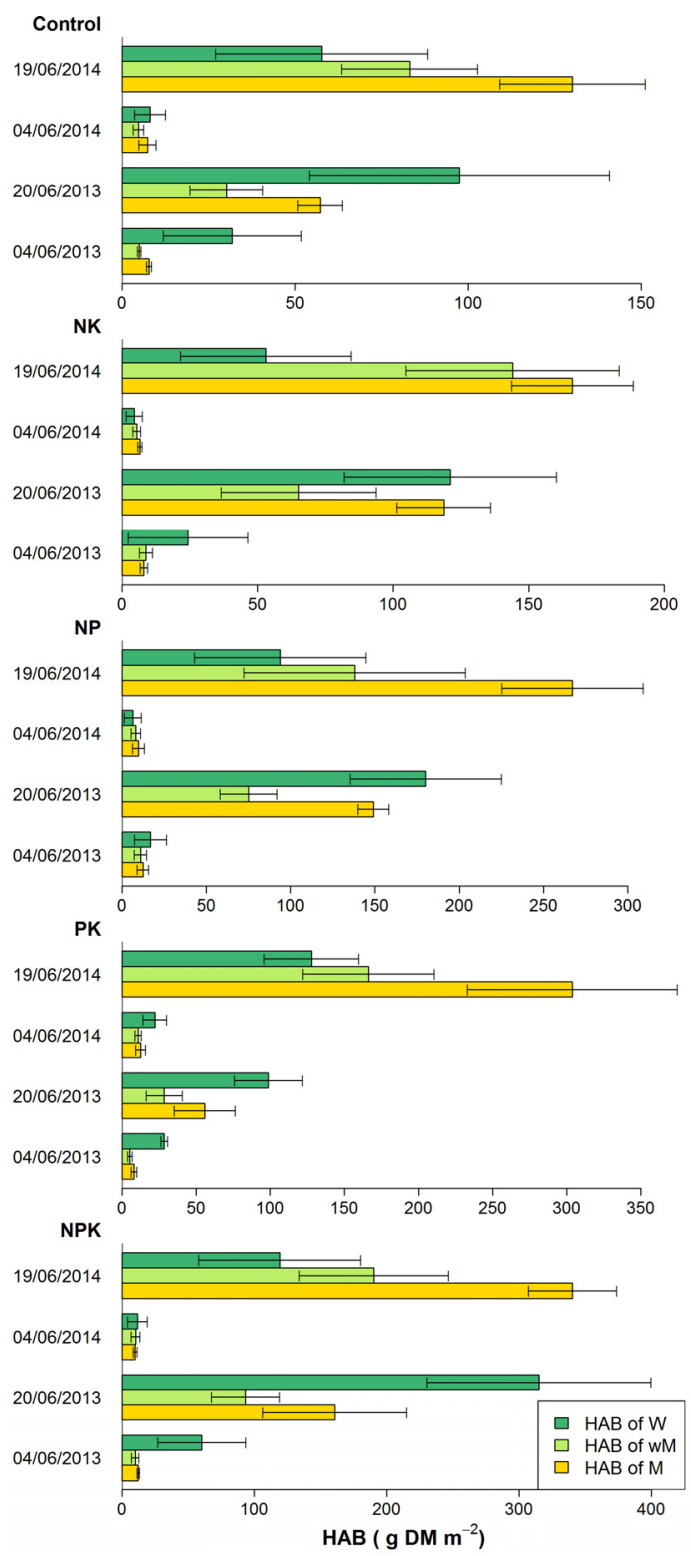

Fig. 5. Averaged HAB (g DM m ${ }^{-2}$ ) of maize (M, yellow), weedy maize (wM, light green) and total weed (W, dark green) for all treatments at Nagyhörcsök (Hungary) on the survey dates in 2013 and 2014. Whiskers are the standard deviations. a limiting factor for crop growth. Only at the Control plot, the median wM HAB growth was higher that the weed-free maize biomass, probably due to the weed could not limited the water sources (Fig. 6). In this study, there was no evidence that competition for water resources and nutrients were a limiting factor on plant growth in the Control plot, however in fertilized plots (NK, NP, PK and NPK) the results suggested that such limitations may have been present. Results from NPK and PK treatments suggested the greatest competition for water source -for instance, biomass productivity was significantly different between Control M and PK fertilized wM (Figs. 4 and 5). These results support the findings of Turral et al. (2011), that NPK fertilization can decrease the unfavourable effects of climatic conditions on the early phenological stages of vegetation. The current study also observed this relationship under PK fertilization.

\section{CONCLUSIONS}

The findings presented suggest that the growth of maize biomass is affected by the available soil water content (SWC), nutrient conditions and presence of weed species during early phenological stages. Treatment responses are consistent with the expectation that early competition between maize and weed for water sources is determined by the available macronutrient content of the soil layers. Variation in the measured range of SWC was higher under weed-maize vegetation than under maize, and this heterogeneity appeared to increase with plant growth. There were significant differences in measured SWC values along the investigated soil profile. With the exception of the PK fertilized plot, where decreases in soil moisture content had a significant effect on DM production within the $10-40 \mathrm{~cm}$ zone, no strong relationship was found between soil fertilization treatments and SWC in either, maize or maizeweed plots. In the PK plot, lack of $\mathrm{N}$ may have negatively affected the competitiveness of maize, allowing weed plants to hamper water intake and growth. This study revealed that maize biomass growth between the BBCH 13 and 19 phenological stages can be significantly influenced by weeds in fertilized plots; while there was no evidence that competition for water hampered plant growth in the Control treatment. These results indicate that soil water balance studies and model simulations should put more focus on variability in the depth- and structuredependent soil water uptake by vegetation at early phenological stages.

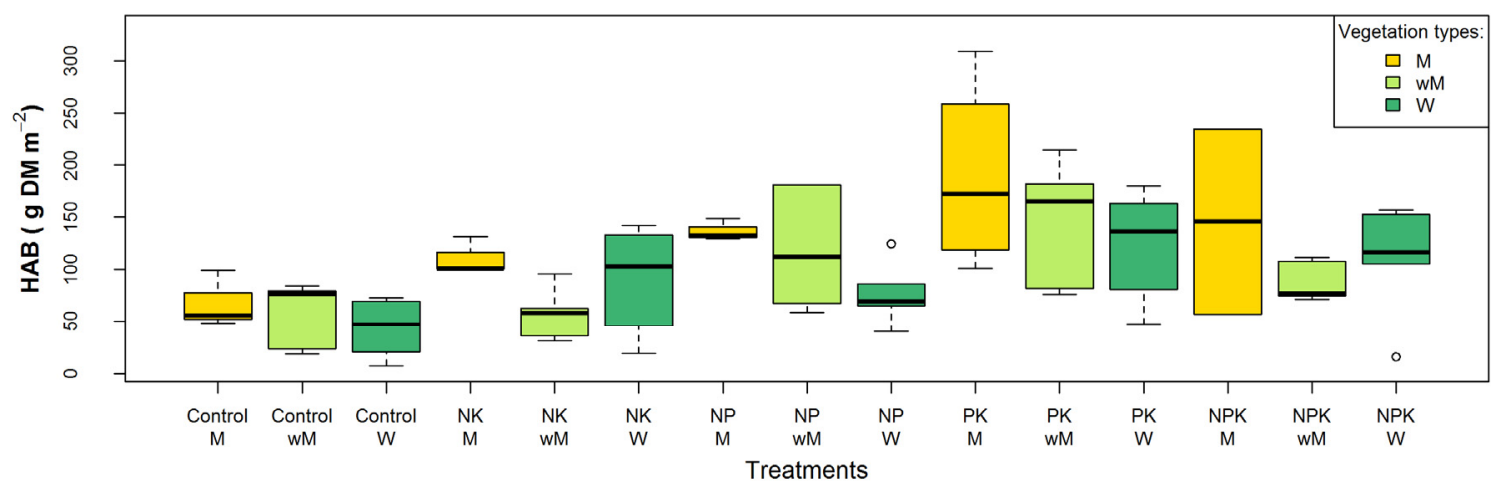

Fig. 6. Variability of the HAB $\left(\mathrm{g} \mathrm{DM} \mathrm{m}^{-2}\right.$ ) absolute growth of maize (M, yellow), weedy-maize (wM, light green) and weed (W, dark green) under different fertilization treatments (doses as in Table 2.) between the 2-4 leaf (BBCH 13) and 8-10 leaf (BBCH 19) phenological stages of maize at Nagyhörcsök (Hungary) in average of two years (2013 and 2014). In each box plot, vertical lines represent, from bottom to top, the $10^{\text {th }}$ percentile, $25^{\text {th }}$ percentile, median, $75 \mathrm{t}^{\mathrm{h}}$ percentile and $90^{\text {th }}$ percentile of observed yields (based on measurements of 3 replicates of treatments). Hollow circles indicate outliers. 
Acknowledgements. The present study has been supported by the Hungarian Scientific Research Fund (Project No. OTKA K 105789). Our sincere thanks to Dr Richard P. Kipling of Aberystwyth University (UK) for contributions to the draft paper, and to Dr Gianni Bellocchi of UREP INRA (FR) for technical advice and inspiration.

\section{REFERENCES}

Abouziena, H.F., El-Saeid, H.M., Amin, A.A.E., 2015. Water loss by weeds: a review. Int. J. ChemTech Res., 7, 1, 323336.

Acciaresi, H.A., Guiamet, J.J., 2010. Below- and above-ground growth and biomass allocation in maize and Sorghum halepense in response to soil water competition. Weed Res., 50, 481-492.

Azeez, J.O., Chikoye, D., Kamara, A.Y., Menkir, A., Adetunji, M.T., 2005. Effect of drought and weed management on maize genotypes and the tensiometric soil water content of an eutric nitrisol in south western Nigeria. Plant Soil, 276, 61-68.

Bassau, S. et.al., 2014. How do various maize crop models vary in their responses to climate change factors? Global Change Biology, 20, 7, 2301-2320.

Berger, A., McDonald, A., Riha, S., 2010. A coupled view of above and below-ground resources capture explains different weed impacts on soil water depletion and crop water productivity in maize. Field Crop Res., 119, 314-321.

Berzsenyi, Z., Árendás, T., Bónis, P., Micskei, G., Sugár, E., 2011. Long-term effect of crop production factors on the yield and yield stability of maize (Zea mays L.) in different years. Acta. Agron. Hung., 59, 3, 191-200.

Brant, V., Pivec, J., Zábransky, P., Hakl, J., 2012. Water consumption by Asteraceae weeds under field conditions. Weed Biol. Manag., 12, 71-83.

Breuer, H., Ács, F., Laza, B., Horváth, Á., Matyasovszky, I., Rajkai, K., 2012. Sensitivity of MM5-simulated planetary boundary layer height to soil dataset: comparison of soil and atmospheric effects. Theor. Appl. Climatol., 109, 3-4, 577590.

Cerrudo, D., Page, E.R., Tollenaar, M., Stewart, G., Swanton, C.J., 2012. Mechanisms of yield loss in maize caused by weed competition. Weed Sci., 60, 225-232.

Diodato, N., Bellocchi, G., 2008. Drought stress patterns in Italy using agro-climatic Indicators. Climate Research, 36, 53-63.

Diodato, N., Ceccarelli, M., Bellocchi, G., 2010. GIS-aided evaluation of evapotranspiration at multiple spatial and temporal climate patterns using geoindicators. Ecological Indicators, 10, 1009-1016.

Fodor, N., 2012. Improving the S-Shape solar radiation estimation method for supporting crop models. The Scientific World Journal, 2012, 768530.

Fodor, N., Csathó, P., Árendás, T., Radimszky, L., Németh, T., 2013. Crop nutrient status and nitrogen, phosphorus, and potassium balances obtained in field trials evaluating different fertilizer recommendation systems on various soils and crops in Hungary. Commun. Soil Sci. Plant Analysis, 44, 5, 9961010 .

Georgescu, E., Toader, M., Cană, L., Gargarita, R., 2014. Draught influence concerning maize leaf weevil (Tanymecus Dilaticollis Gyll) attack on maize crops at Nardi Fundulea. Scientific Papers. Series A. Agronomy, 57, ISSN Online 2285-5807.
Hall, M.R., Swanton, C.J., Anderson, G.W., 1992. The critical period of weed control in grain corn (Zea mays L.). Weed Sci., 40, 441-447.

Kádár, I., Csathó, P., 2015. The interaction between nitrogen and copper studied in open field experimental corn. Agrokémia és Talajtan, 64, 1, 177-188.

Kamuti, M., Mazsu, N., Csathó, P., Lehoczky, É., 2015. Effects of nutrient supply on the weed flora composition in early growth stage of maize. Crop Prod., 64 (Suppl.), 75-78.

Kazinczi, G., Béres, I., Torma, M., Kovács, I., 2008. Critical competition period of maize. Magyar gyomkutatás és technológia, 9, 1, 23-30. (In Hungarian.)

Kivuva, B.M., Mburu, M.W.K., Maina, J.M., Murdoch, A.J., 2014. The effects of maize planting density and weeding regimes on light and water use. Journal of Agricultural Science, 6, 1, 215-229.

Lehoczky, É., 2004. The role of weeds in the nutrient cycle of soil - plant system. DSc Dissertation. Keszthely, Hungary, 146 p. (In Hungarian.)

Lehoczky, É., Reisinger, P., Kőmíves, T., 2005. Loss of nutrients caused by excessive weediness at the early stage of maize vegetation period. Commun. Soil Sci. Plant Analysis, 36, 4-6, 415-422.

Lehoczky, É., Németh, T., Reisinger, P., Radimszky, L., Kömíves, T., 2006. Effect of weediness on the water content of the soil: a field study. Commun. Soil Sci. Plant Analysis, 37, 2673-2678.

Lehoczky, É., Busznyák, J., Gólya, G., Pálmai, O., 2012. Green water - Ambrosia artemisiifolia L. on winter wheat stubble. Crop Production, 61, Suppl., 259-262.

Lehoczky, É., Márton, L., Nagy, P., 2013. Competition for nutrients between cold-tolerant maize and weeds. Commun. Soil Sci. Plant Analysis, 44, 1-4, 526-534.

Lehoczky, É., Kamuti, M., Mazsu, N., Tamás, J., SáringerKenyeres, D., Gólya, G., 2014. Influence of NPK fertilization on weed flora in maize field. Agrokémia és Talajtan, 63, $1,139-148$.

Lehoczky, É., Gólya, G., Tamás, J., Németh, T., 2015. Biodiversity and biomass production of weeds in a long-term fertilization experiment. Commun. Soil Sci. Plant Analysis, 46, 1, 390-398.

Lichner, L., Holko, L., Zhukova, N., Schacht, K., Rajkai, K., Fogor, N., Sándor, R., 2012. Plants and biological soil crust influence the hydrophysical parameters and water flow in an Aeolian sandy soil. J. Hydrol. Hydromech., 60, 4, 309-318.

Lichner, L., Capuliak, J., Zhukova, N., Holko, L., Czachor, H., Kollár, J., 2013. Pines influence hydrophysical parameters and water flow in a sandy soil. Biologia, 68, 1104-1108.

Mantovani, D., Veste, M., Gypser, S., Halke, C., Koning, L., Freese, D., Lebzien, S., 2014. Transpiration and biomass production of the bioenergy crop giant knotweed igniscum under various supplies of water and nutrients. J. Hydrol. Hydromech., 62, 4, 316-323.

Martinez, G., Pachepsky, Y.A., Vereecken, H., Hardelauf, H., Herbst, M., Vanderlinden, K., 2013. Modeling local control effects on the temporal stability of soil water content. J. Hydrol., 481, 106-118.

Matthews, K.B., Rivington, M., Buchan, K., Miller, D.G., Bellocchi, G., 2008. Characterising the agro-meteorological implications of climate change scenarios for land management stakeholders. Climate Research, 37, 59-75.

Nichols, V., Verhulst, N., Cox, R., Govaerts, B., 2015. Weed dynamics and conservation agriculture principles: A review. Field Crop Res., 18, 56-68. 
Patterson, D.T., 1995. Effects of environmental stress on weed/crop interactions. Weed Sci., 43, 483-490.

Patterson, D.T., Flint, E.P., 1983. Comparative water relations, photosynthesis, and growth of soybean (Glycine max) and seven associated weeds. Weed Sci., 31, 318-323.

Pivec, J., Brant, V., 2009. The actual consumption of water by selected cultivated and weed species of plants and the actual values of evapotranspiration of the stands as determined under field conditions. Soil Water Res., 4, 2, 39-48.

Pivec, J., Brant, V., Hamouzová, K., 2011. Evapotranspiration and transpiration measurements in crops and weed species by the Bowen ratio and sapflow methods under the rainless region conditions. In: Gerosa, G. (Ed.): Evapotranspiration From Measurements to Agricultural and Environmental Applications. InTech Europe, Croatia, pp. 125-140.

Rajcan, I., Swanton, C.J., 2001. Understanding maize-weed competition: resource competition, light quality and the whole plant. Field Crop Res., 71, 139-150.

Rékási, M., Filep, T., 2006. Effect of microelement loads on the element fractions of soil and plant uptake. Agrokémia és Talajtan, 55, 213-223.

RStudio Team, 2015. RStudio: Integrated Development for R. RStudio, Inc., Boston, MA. URL http://www.rstudio.com/

Sándor, R., 2014. Scale related problems of the soil-plantatmosphere system. Scale dependency of soil hydrological properties as well as of meteorological data. Ph.D. Thesis, Szeged, $141 \mathrm{p}$.

Sándor, R., Lichner, L., Filep, T., Balog, K., Lehoczky, É., Fodor, N., 2015. Spatial variability of hydrophysical properties of fallow sandy soils. Biologia, 70, 11, 1468-1473.

Shen, Q., Gao, G., Fu, B., Lü, Y., 2014. Soil water content variations and hydrological relations of the croplandtreebelt-desert land use pattern in an oasis-desert ecotone of the Heihe River Basin, China. Catena, 123, 52-61.

Si, J., Feng, Q., Wen, X., Xi, H., Yu, T., Li, W., Zhao, C., 2015. Modeling soil water content in extreme arid area using an adaptive neuro-fuzzy inference system. J. Hydrol., 527, 679-687.

Singh, B., Singh, G., 2004. Influence of soil water regime on nutrient mobility and uptake by Dalbergia sissoo seedlings. Tropical Ecology, 45, 2, 337-340.
Song, C.Y., Zhang, X.Y., Liu, X.B., Sui, Y.Y., Li, Z.L., 2010. Impact of long term fertilization on soil water content in Haploborolls. Plant Soil Environ., 56, 9, 408-411.

Turral, H., Burke, J., Faurés, J.M., 2011. Climate Change, Water and Food Security. Food and Agriculture Organisation of the United Nations, Rome, Italy, $175 \mathrm{p}$.

Valerio, M., Lovelli, S., Perniola, M., Di Tommaso, T., Ziska, L., 2013. The role of water availability on weed-crop interactions in processing tomato for southern Italy. Acta Agr. Scand. B-S. P., 63, 1, 62-68.

Várallyay, G., 2011. Water-dependent land use and soil management in the Carpathian Basin. Crop Production, 60, Suppl., 297-300.

Wang, J., Liu, W.Z., Dang, T.H., Sainju, U.M., 2013. Nitrogen fertilization effect on soil water and wheat yield in the Chinese Loess Plateau. Agron. J., 105, 143-149.

Wang, S., Huang, J., Li, J., Rivera, A., McKenney, D.W., Sheffield, J., 2014. Assessment of water budget for sixteen large drainage basis in Canada. J. Hydrol., 512, 1-15.

Wang, H., Jiang., X., Wan, L., Han, G., Guo, H., 2015. Hydrogeochemical characterization of groundwater flows systems in the discharge area of a river basin. J. Hydrol., 527, 433441.

Wendel, S., Moore, T., Bubier, J., Blodau, C., 2011. Experimental nitrogen, phosphorus, and potassium deposition decreases summer soil temperatures, water contents, and soil $\mathrm{CO}_{2}$ concentrations in a northern bog. Biogeosciences, 8, 585-595.

Wiese, A.F., Vandiver, C.W., 1970. Soil moisture effects on competitive ability of weeds. Weed Sci., 18, 518-519.

Yeganehpoor, F., Salmasi, S.Z., Abedi, G., Samadiyan, F., Beyginiya, V., 2015. Effects of cover crops and weed management on crop yield. Journal of the Saudi Society of Agricultural Sciences, 14, 178-181.

Received 2 September 2015 Accepted 16 December 2015 